\title{
EFEKTIFITAS KOAGULAN POLY ALUMINIUM CHLORIDE (PAC) DALAM PENURUNAN NILAI KEKERUHAN SUNGAI CIJANGGEL
}

\author{
Indry Kemala Sani \\ Jurusan Teknik Lingkungan, Fakultas Arsitektur Lanskap dan Teknologi Lingkungan, \\ Universitas Trisakti, Jakarta, Indonesia
}

Email korespondensi: indry08215030@ std.trisakti.ac.id

\begin{abstract}
ABSTRAK
Dalam penelitian ini bertujuan untuk mengetahui kinerja PAC dalam penurunan nilai kekeruhan di Sungai Cijanggel. Sampel air baku diambil untuk diuji nilai kekeruhan awalnya kemudian pada sampel tersebut ditambahkan koagulan PAC. Setelah itu sampel diaduk dengan pengadukan cepat yang disebut koagulasi dan pengadukan lambat yang disebut flokulasi. Setelah unit flokulasi sampel dibiarkan mengendap dalam waktu 30 menit sehingga dapat diukur penurunan nilai kekeruhan sampel tersebut. Pemberian dosis koagulan yang diberikan kedalam 1 liter sampel air masing-masing yaitu sebesar 5 ppm, 10 ppm, 15 ppm, 20 ppm dan 25 ppm dengan kecepatan pengadukan cepat yaitu sebesar $120 \mathrm{rpm}$ selama 1 menit dan kecepatan pengadukan lambat yaitu $40 \mathrm{rpm}$ selama 15 menit. Dalam penelitian ini diperoleh nilai penurunan kekeruhan paling efektif yaitu pada dosis $25 \mathrm{ppm}$ dengan nilai kekeruhan yaitu 0,43 NTU.
\end{abstract}

Kata Kunci: koagulasi; flokulasi; Poly Aluminium Chloride (PAC)

\section{PENDAHULUAN}

Dalam proses penjernihan air baku yang bersumber dari air pemukaan dibutuhkan pengolahan air yang meliputi unit intake, koagulasi, flokulasii, sedimentasi dan filtrasi. Dalam pengolahannya, unit yang paling berpengaruh dalam penurunan nilai kekeruhan air baku yaitu pada unit koagulasi dan flokulasi. Menurut Reynolds (1982) pada unit koagulasi atau pengadukan cepat (flash mixing) penambahan koagulan berfungsi untuk mendestabilisasi partikel-partiikel koloid dan suspended solid. Unit flokulasi bertujuan untuk menggabungkan partikel-partikel koloid sehingga partikel-partikel menjadi berukuran besar dan dapat mengendap pada proses pengolahan selanjutnya (Montgomery, 1985). Sungai Cijanggel merupakan sumber air bersih bagi penduduk di Kota Cimahi, agar dapat digunakan atau dikonsumi masyarakat diperlukannya pengolahan yang dilakukan oleh PDAM Tirta Raharja Kabupaten Bandung. Dalam mengolah air baku tersebut umumnya koagulan yang sering digunakan pada proses koagulasi yaitu Poly Aluminium Chloride (PAC). Tujuan dari penulisan ini adalah untuk mengetahui efektifitas koagulan Poly Aluminium Chloride (PAC) dalam penurunan nilai kekeruhan di Sungai Cijanggel.

\section{TINJAUAN PUSTAKA}

Menurut Peraturan Menteri Kesehatan RI Nomor 492 Tahun 2010 tentang Persyaratan Kualitas Air Minum, air minum merupakan air yang melalui proses pengolahan atau tanpa proses pengolahan yang memenuhi syarat kesehatan dan dapat langsung diminum. Air minum harus terjamin dan baik bagi kesehatan baik secara fisika, kimia dan mikrobiologis. Jika hal ini telah terpenuhi maka kualitas hidup manusia akan meningkat dan bisa melaksanakan kegiatan sehari-hari dengan baik.

Pengolahan atau penjernihan air merupakan cara yang dilakukan untuk menghilangkan kontaminan-kontaminan yang terlarut dalam air, sehingga dihasilkan air yang dapat digunakan untuk kehidupan manusia. Beberapa kontaminan yang dihilangkan selama proses penjernihan air yaitu bakteri, alga, virus, bahan kimia dan logam berat yang dapat menimbulkan masalah bagi kehidupan manusia.

Air baku yang biasa digunakan dalam proses pengolahan air minum adalah air permukaan dan kualitasnya tergantung seberapa besar beban pencemaran selama air tersebut dari hulu hingga disadap dilokasi pengolahan. Berdasarkan Peraturan Pemerintah No.82 Tahun 2001 Kelas I beberapa karakteristik air baku seperti fisika, kimia dan mikrobiologi yang harus memenuhi baku mutu tersebut yaitu air untuk peruntukan air baku air minum dan atau peruntukan lain yang 
mensyaratkan mutu air yang sama dengan kegunaan tersebut. Air minum yang aman bagi kesehatan apabila memenuhi persyaratan fisika, mikrobiologis, kimiawi dan radioaktif yang dimuat dalam parameter wajib dan parameter tambahan.

\section{Unit Koagulasi}

Koagulasi adalah penambahan dan pengadukan cepat (flash mixing) koagulan yang bertujuan untuk mendestabilisasi partikel-partikel koloid dan suspended solid (Reynolds,1982). Sedangkan menurut Kawamura (2000) koagulasi didefinisikan sebagai proses destabilisasi muatan koloid dan padatan tersuspensi termasuk bakteri dan virus, dengan suatu koagulan. Pemilihan jenis dari unit koagulasi tergantung pada karakteristik koagulan, partikel dan kualitas air. Beberapa faktor utama yang mempengaruhi koagulasi dan flokulasi menurut Reynolds dan Richards 1996 yaitu:

a. Nilai kekeruhan air yang diolah

b. Kandungan zat padat tersuspensi

c. Temperatur air yang diolah

d. Derajat $\mathrm{pH}$

e. Konsentrasi dan komposisi kation dan anion dalam air

f. Lamanya pengadukan pada proses koagulasi dan flokulasi

g. Dosis dan sifat dasar koagulan

h. Keperluan koagulan pembantu

Jenis pengadukan terbagi tiga yaitu pengadukan hidrolis, pengadukan mekanis dan pengadukan pneumatis. Pengadukan hidrolis menggunakan gaya gravitasi yang memanfaatkan aliran air untuk tenaga pengaduknya. Pengadukan mekanis menggunakan peralatan seperti motor, poros pengaduk dan alat pengaduk yang digerakkan dengan tenaga listrik. Pengadukan pneumatis menggunakan udara atau gas yang berbentuk gelembung untuk tenaga pengaduknya.

Dalam pembetukan flok, penambahan bahan koagulan sangat berpengaruh. jenis koagulan yang sering dipakai dalam proses pemurnian air baku adalah Poly Aluminiumuniium Chloride (PAC), aluminium sufat $\left(\mathrm{Al}_{2}\left(\mathrm{SO}_{4}\right)_{3}\right)$, ferri klorida $\left(\mathrm{FeCl}_{3}\right)$, dan ferri sulfat $\left(\mathrm{Fe}_{2}\left(\mathrm{SO}_{4}\right)_{3}\right)$. Bahan koagulan yang paling sering digunakan oleh masyarakat adalah aluminium sulfat atau yang lebih dikenal dengan tawas. PAC adalah garam khusus pada pembuatan aluminium klorida yang mampu memberikan daya koagulasi dan flokulasi yang lebih kuat dari pada aluminium yang biasa dan garam-garam besi seperti aluminium sulfat atau ferri klorida. Kegunaani dari PAC adalah sebagai koagulan atau flokulan untuk menguraikan larutan yang keruh dan menggumpalkan partikel, sehingga bisa untuk memisahkan dari medium larutannya. Keuntungan penggunaan $P A C$ sebagai koagulan dalam proses penjernihan air adalah sebagai berikut :

1. Korosivitas rendah dikarenakan $P A C$ merupakan koagulan yang bebas sulfat sehingga aman dan mudah dalam penyimpanan dan transportasinya.

2. Koagulan yang digunakan akan membentuk logam hidroksida. Penggunaan koagulan aluminium sulfat menyebabkan pelepasan sebuah ion hidrogen untuk tiap gugus hidrogen yang dihasilkan. Hasil ion hidrogen menyebabkan turunnya $\mathrm{pH}$ yang cukup signifikan, jadi air yang diolah menjadi lebih asam. Pada penggunaan PAC sebagai koagulan, $\mathrm{pH}$ air hasil pengolahan tidak mengalami penurunan $\mathrm{pH}$ yang cukup tajam seperti pada penggunaan koagulan aluminium sulfat.

\section{Unit Flokulasi}

Flokulasi merupakan proses penggabungan dari partikel-partikel menjadi flok yang berukuran besar, hal ini bertujuan untuk mempercepat jumlah tumbukan yang menyebabkan pengelompokan partikel koloid elektrolit tidak stabil menjadi ukuran yang bisa diendapkan. Untuk mempermudah penggabungan partikel-partikel yang telah mengalami destabilisasi, kontak antar partikel dibantu oleh pengadukan.

Montgomery (1985) mengatakan bahwa hal-hal yang harus diperhatikan dalam mendesain unit flokulasi yaitu:

a. Kekeruhan air baku dan partikulat tersuspensi termasuk distribusi ukuran partikel dan karakteristik muatan permukaan.

b. Temperatur air. 
c. Tipe pengolahan di hilir.

d. Kondisi setempat.

Selain itu dilihat pula hubungan antara suhu dan proses koagulasi dan flokulasi :

a. pH yang optimum untuk koagulasi akan berubah-ubah karena pengaruh suhu bila digunakan koagulan aluminium.

b. Dosis akan bertambah bila suhu dalam suspensi turun.

c. Untuk dosis tertentu, effluent dari proses koagulasi dan flokulasi akan mempunyai kekeruhan yang lebih tinggi bila suhu rendah.

Salah satu jenis koagulasi pengaduk cepat yaitu flokulasi hidrolis yang merupakan sistem pengadukan yang tidak membutuhkan peralatan mekanis. Pada prinsipnya pengadukan secara hidrolis harus dilakukan dengan perencanaan kehilangan tekanan yang tepat. Dengan flokulasi hidrolis, energi yang tersedia konstan atau tidak berubah. Jenis flokulasi ini merupakan saluran bersekat (baffled channel).

Flokulasi baffle channel dibedakan menjadi dua, yaitu around-the-end baffles (aliran horizontal) dan over-and-under baffles (aliran vertikal). Menurut Schulz dan Okun (1984), flokulasi jenis aliran horizontal lebih baik dibandingkan jenis aliran vertical karena lebih mudah dalam pemeliharaan seperti pengeringan dan pembersihan; namun untuk aliran horizontal diperlukan lahan yang lebih luas dari aliran vertikal. Headloss yang dipengaruhi oleh derajat pengadukan dapat diubah dengan menambah atau mengurangi sekat (baffles).

Proses pemurnian air dilakukan dengan cara mencampurkan bahan koagulan PAC kedalam gelas beker 1 liter yang berisi air baku Sungai Cijanggel. Dalam penelitian ini dilakukan dua kali percobaan dengan 6 variasi dosis sebear 5 ppm, 10 ppm, 15 ppm, 20 ppm dan 25 ppm. Nilai kekeruhan awal percobaan pertama yaitu 20,9 NTU sedangakan pada percobaan kedua sebesar 35,4 NTU. Hasil percobaan dapat dilihat pada Tabel 1 dan grafik hasil percobaan terdapat pada Gambar 1.

Tabel 1. Percobaan Menggunakan Koagulan PAC

\begin{tabular}{ccccc}
\hline \multirow{2}{*}{ Dosis $(\mathbf{p p m})$} & \multicolumn{3}{c}{ Koagulan PAC } & \\
\cline { 2 - 5 } & NTU & $\mathbf{p H}$ & NTU & pH \\
\cline { 2 - 5 } & 20,9 & 7,3 & 35,4 & 7,28 \\
\hline 0 & 7,33 & 7,28 & 25,7 & 7,24 \\
\hline 5 & 2,76 & 7,27 & 16,3 & 7,21 \\
\hline 10 & 1,62 & 7,17 & 7,81 & 7,18 \\
\hline 15 & 0,84 & 7,14 & 2,81 & 7,14 \\
\hline 20 & 0,43 & 7,11 & 0,67 & 7,12 \\
\hline 25 & & & &
\end{tabular}

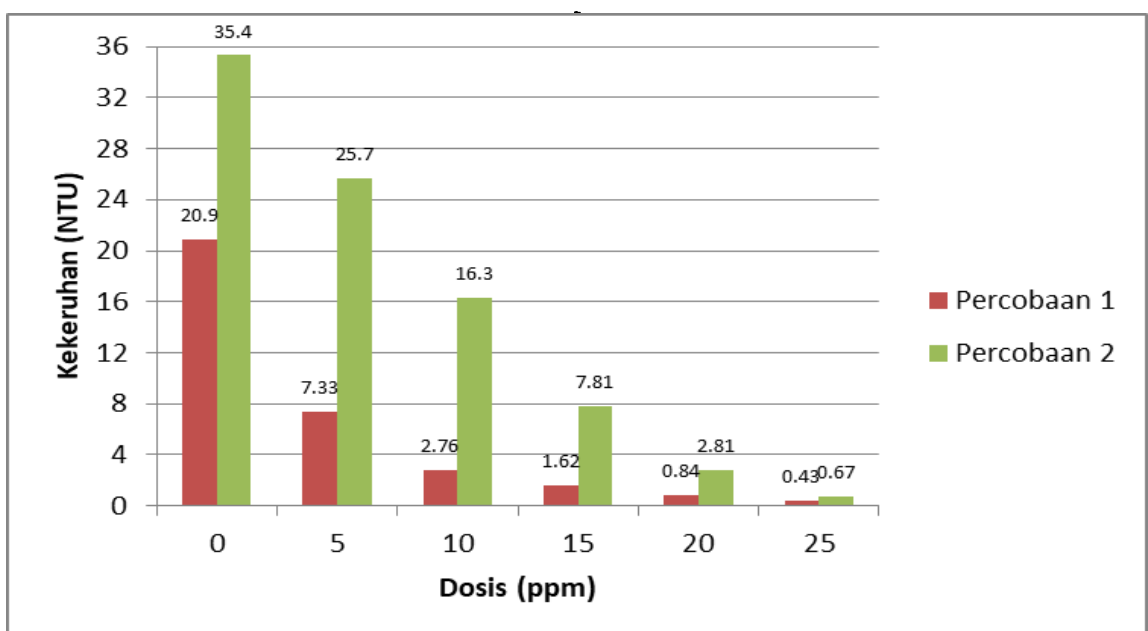

Gambar 2. Percobaan Menggunakan Koagulan PAC

Dari Gambar 1 dan Tabel 1 dapat dilihat bahwa dengan variai dosis 0 ppm hingga 25 ppm, dari nilai kekeruhan awal yang tidak memenuhi syarat air minum yang diteteapkan setelah dilakukannya jartest didapatkannya hasil bahwa nilai kekeruhan turun dengan penambahan dosis yang semakin besar. 


\section{PENUTUP}

Dosis koagulan PAC yang paling efektif pada percobaan di Sungai Cijanggel ini adalah dengan dosis 25 ppm yang menurunkan nilai kekeruhan yang awalnya 20,9 NTU menjadi 0,43 NTU dan yang kekeruhan awalnya 35,4 NTU berubah menjadi 0,67 NTU.

\section{DAFTAR PUSTAKA}

Adrian Dwi Putra, Rositayanti Hadisoebroto, Widyo Astono. 2018. Design of Water Treatment Plant in East Bekasi District, Bekasi City, West Java. Indonesian Journal of Urban and Environmental Technology.1(1): 207-217.

DOI: http://dx.doi.org/10.25105/psnkb.v1i1.2900

Kawamura, Susuma. 2000. In25grated Design on Operation of Water Treatment Facilities. New York: John Wiley and Sons.

Montgomery, J M. 1985. Water Treatment: Principles and Design. New York : Wiley.

Peraturan Pemerintah No 82 Tahun 2001, Pengolahan Kualitas Air dan Pengendalian Pencemaran Air.

PERMENKES RI NO 492/MENKES/SK/IV/2010. Tentang Persyaratan Kualitas Air Minum.

Reynolds T.D. 1982. Unit Operations and Processes in Environmental Engineering. California: Wadsworth. Inc.

Reynolds, T.D, and P.A Richards. 1996. Unit Operations and Processes in Environmental Engineering. New York: PWS Publishing Company.

Schultz, C.R, and D.A Okun. 1984. Surface Water Treatment for Communities in Developing Countries. New York: John Wiley and Sons. 